Meta

Journal des traducteurs

Translators' Journal

\title{
Translating Politeness in Bilingual English-Spanish Business Correspondence
}

\section{Pedro A. Fuertes-Olivera et Sandro Nielsen}

Volume 53, numéro 3, septembre 2008

URI : https://id.erudit.org/iderudit/019246ar

DOI : https://doi.org/10.7202/019246ar

Aller au sommaire du numéro

Éditeur(s)

Les Presses de l'Université de Montréal

ISSN

0026-0452 (imprimé)

1492-1421 (numérique)

Découvrir la revue

Citer cet article

Fuertes-Olivera, P. A. \& Nielsen, S. (2008). Translating Politeness in Bilingual English-Spanish Business Correspondence. Meta, 53(3), 667-678.

https://doi.org/10.7202/019246ar
Résumé de l'article

La courtoisie est un élément très important de la communication dans l'entreprise, et elle joue un rôle essentiel dans toute situation d'utilisation de plusieurs langues. Normalement, les traducteurs emploient des dictionnaires bilingues pour résoudre des problèmes d'ordre culturel, dans le cadre de la communication d'entreprise à laquelle participent habituellement des personnes de traditions culturelles différentes.

Dans la majorité des cas, ces dictionnaires n'offrent pas d'indications pratiques très valables. Ainsi, pour traduire ou rédiger des lettres commerciales en anglais ou en espagnol, un traducteur peut avoir recours au dictionnaire The Oxford Business Spanish Dictionary. Spanish-English/English-Spanish qui offre quelques exemples et explique certaines caractéristiques. Cependant, l'analyse de cette partie du dictionnaire nous montre que l'information est peu utile puisqu'on n'y explique pas les ressemblances et les différences entre les lettres, dans les deux langues.

Ceci pose problème en ce qui a trait à la courtoisie : aussi croyons-nous qu'il serait nécessaire de réorganiser la partie du dictionnaire afin de donner des indications plus adaptées aux besoins des usagers du dictionnaire.
Ce document est protégé par la loi sur le droit d'auteur. L'utilisation des services d’Érudit (y compris la reproduction) est assujettie à sa politique d'utilisation que vous pouvez consulter en ligne.

https://apropos.erudit.org/fr/usagers/politique-dutilisation/ 


\title{
Translating Politeness in Bilingual English- Spanish Business Correspondence
}

\author{
PEDRO A. FUERTES-OLIVERA \\ Universidad de Valladolid, Valladolid, Spain \\ pedro@tita.emp.uva.es
}

\author{
SANDRO NIELSEN \\ University of Aarhus, Aarhus, Denmark \\ sn@asb.dk
}

\section{RÉSUMÉ}

La courtoisie est un élément très important de la communication dans l'entreprise, et elle joue un rôle essentiel dans toute situation d'utilisation de plusieurs langues. Normalement, les traducteurs emploient des dictionnaires bilingues pour résoudre des problèmes d'ordre culturel, dans le cadre de la communication d'entreprise à laquelle participent habituellement des personnes de traditions culturelles différentes.

Dans la majorité des cas, ces dictionnaires n'offrent pas d'indications pratiques très valables. Ainsi, pour traduire ou rédiger des lettres commerciales en anglais ou en espagnol, un traducteur peut avoir recours au dictionnaire The Oxford Business Spanish Dictionary. Spanish-English/English-Spanish qui offre quelques exemples et explique certaines caractéristiques. Cependant, l'analyse de cette partie du dictionnaire nous montre que l'information est peu utile puisqu'on n'y explique pas les ressemblances et les différences entre les lettres, dans les deux langues.

Ceci pose problème en ce qui a trait à la courtoisie: aussi croyons-nous qu'il serait nécessaire de réorganiser la partie du dictionnaire afin de donner des indications plus adaptées aux besoins des usagers du dictionnaire.

\begin{abstract}
Politeness is an important element in interlingual business communication. Translators use bilingual dictionaries as tools helping then in business discourse across cultures, but dictionaries do not contain the relevant pragmatic information. The functions of dictionaries are used to determine which pragmatic information types are needed when translating business letters. The analysis focuses on a Spanish-English business dictionary and its treatment of politeness in special sections dealing with business correspondence. The findings show that the treatment is insufficient, because users' business-language competence does not enable them to express the right level of politeness. Bilingual dictionaries should offer a systematic treatment of cultural and genre-specific means of expressing politeness in contrastive, informative texts showing the specific uses of politeness in business discourse. Finally, proposals on what to include and how this can be done are made, with a view to helping translators.
\end{abstract}

\section{MOTS-CLÉS/KEYWORDS}

business correspondence, politeness, English, Spanish, dictionary 


\section{Introduction}

As a culturally dependent element, politeness allows discourse participants to save their face by performing different discoursal strategies. Central to the concept of politeness is the concept of "face," which derives from Goffman (1972) and was adapted by Brown and Levinson $(1978,1987)$, in order to differentiate between both positive and negative aspects. Negative face hangs together with one's desire to be unimpeded in one's actions, whereas positive is linked to the desire to be approved of by others. Positive politeness indicates closeness, solidarity and intimacy between participants, whereas negative politeness indicates social distance and non-encroachment.

Many studies have so far applied politeness theory in studies of business communication since the pioneer work of Pilegaard (1990) who has demonstrated that the level, form and distribution of positive and negative politeness in business letters correlate with sender status, that it varies as a function of the dynamics of the course of business communication, and that the analysis of politeness strategies on the text level gives valuable insight into the norms that govern business communication. More recently, works by Bargiela-Chiappini and Harris (1996), Pilegaard (1997) Yeung (1997), and Flowerdew and Wan (2006) have followed suit and have added more parameters to the analysis.

One of these refers to combining ethnographic dimensions and structural analysis. If we accept that written communication is a process that takes place between individuals operating within well-defined social environments, a clear picture of as many social environments as possible is needed. For example, we need to know if the rules are determined by cultural traditions alone, by genre conventions alone, or by a mixture of them. In other words, if there is variation regarding the treatment of politeness in written business texts, we have to find out the extent of the possible variation. At least two possible orientations can be taken. One deals with the possibility of investigating politeness intralinguistically by commenting on similarities and differences found in the diverse genres associated with written business correspondence in the same language. Another possibility refers to identifying interlinguistic similarities and differences by focussing on the same genre in two or more languages. We combine both objectives. Our aim is to present a description of business letters in English and Spanish as they appear in the middle texts of a bilingual (often referred to as 'translation') dictionary, and then draw some conclusions which can be useful for translation and lexicographical purposes, as we should not forget that translators everywhere typically rely on dictionaries in carrying out their translation objectives.

\section{Translation dictionaries and their functions}

Lexicographic theories focusing on translation dictionaries have predominantly focussed on general language dictionaries. Moreover, they have been of a contemplative nature, i.e., have analysed existing dictionaries and described their constitution. However, during the last 20 years lexicographers have increasingly turned their attention to bilingual specialised dictionaries and realised that a certain basis is necessary for compiling good and user-friendly LSP dictionaries. The first monograph on bilingual specialised dictionaries was Nielsen (1994), and this was followed by 
Bergenholtz and Tarp (1995). These two books show that dictionaries can generally be improved if lexicographers use a number of principles for compiling bilingual LSP dictionaries, involving such aspects as dictionary user research, the selection and presentation of domain-specific entry words, and the selection and presentation of special-language collocations and phrases as well as conventions, genre-specific and cultural. More recently, Bergenholtz and Tarp (2002) and Tarp (2004: 224-225) have advocated a shift of focus by proposing that modern lexicography should view dictionaries as tools that provide assistance in various situations and by introducing a transformative theory of lexicography. This is the modern theory of dictionary functions and it is transformative because it focuses on dictionaries and user needs in order to develop new principles for dictionary research and dictionary making.

Bilingual business dictionaries can be designed for various functions that represent types of use-situations. As described in Bergenholtz and Nielsen (2006: 287) dictionary users may need information in connection with ongoing acts of communication. A typical situation is where users are producing texts in a foreign language, and they want to consult their dictionary in order to find information that helps them produce the texts. The users may also be revising or editing texts written in a foreign language and consult their dictionary to find help to solve problems related to, inter alia, inflectional, syntagmatic and paradigmatic matters. Similarly, teachers correcting translations or grading examination papers may need to check something in a dictionary, either related to linguistic or extra-linguistic information. Bilingual dictionaries are most often used by persons translating texts from or into their native language, for instance students completing translation exercises and professional translators translating fiction or non-fiction. Bilingual business dictionaries may also be used by someone reading a foreign-language text and who needs to consult a dictionary in order to understand a passage or a single word. These types of usesituations are all catered to by bilingual business dictionaries, and the relevant dictionary functions are called communicative functions.

Other dictionary functions may be independent of ongoing communicative acts. Dictionary users may want to gain general knowledge about something, for instance general cultural knowledge about linguistics as a wish to broaden their knowledge bases. Users may also want to gain specific knowledge about a single topic almost sporadically, for instance the inflectional pattern of an irregular verb or when the euro was introduced. Finally, users may want to learn something specific about language usage, for example social and cultural conventions, so that they will be prepared for discussions with foreign customers, presenting business plans etc. These types of use-situations are also catered to by bilingual business dictionaries and the relevant dictionary functions are called cognitive functions; the users want knowledge and the lexicographers provide it at a cognitive level.

Linking dictionary functions to user needs involves the identification of user competences. The factual competence, which concerns the knowledge of business, the linguistic competence, i.e., the knowledge of general language (LGP) and business language (LSP), the textual competence, which is the knowledge of textual conventions for standard-language and specialised texts in the relevant domains in both languages, and the cultural competence, i.e., knowledge facilitating cross-cultural interaction, determine how users will actually use a dictionary in a particular type of situation. When these competences have been identified, lexicographers will have 
a good indication of the environment in which their translation dictionary will be rooted and which types of data users need in the relevant communicative and cognitive use-situations.

When use-situations and user needs have been properly identified, lexicographers can proceed to select the information they have found necessary to include in their dictionary, so that it can provide users with the help they require when they translate business texts. In order to do so it is necessary to study the extra-lexicographic environment concerned, i.e., what happens outside the dictionary when users translate business texts, and relate these findings to the lexicographic theoretical basis and the dictionary itself.

\section{Identifying stages in translation}

Lexicographers should prepare a general outline of the function of business translation in order to determine the other lexicographic choices they have to make. The translating of business texts between English and Spanish shares its basic elements with the stages in translating generally. For the purposes of bilingual business dictionaries, it is relevant to establish the most basic stages of translating, as a bilingual dictionary is unlikely to provide help in all of them; we therefore propose that lexicographers identify those stages where the dictionary may provide help.

Broadly speaking, the translation process may be divided into a planning, an execution and a finalisation stage. The execution stage is the only one that is directly relevant to lexicographers, as this is where translation proper takes place. The finalisation stage is partly relevant, because it concerns proofreading, printing and copying of the final text; proofreading is the only element that has lexicographic relevance, as it is the last step before printing and copying, at which stage the target text has in effect been completed. Translation dictionaries are unlikely to provide sufficient help in the planning stage, and this phase is better covered by translation manuals and guidelines, though some of the elements, for instance design of the target text, may affect the execution stage.

Lexicographers of business translation dictionaries should focus on the execution stage and the proofreading phase. Following Bell (2000: 20-21) and Nord (2005: 35), the execution stage involves the analysis of the SL text, the transfer of the meaning of the ST message into TL, and the recoding of the message into a realised TL text. Being an iterative process, translating includes the drafting, revision and editing of the target text. A translation dictionary may therefore be described as a tool that has been designed to help users draft, revise and edit TL texts, and lexicographers must include information that support these activities. The incorporation of such information is fairly straightforward, as most - sometimes all - the data can be placed in the dictionary articles, but the exact location will depend on the structure for distributing the information adopted by the lexicographers.

We believe that information dealing with the design of TL business texts may be difficult to include in translation dictionaries, particularly in the articles, but if lexicographers decide to include such information, we propose that it should be placed in separate dictionary sections. Nielsen (1994: 107-108) suggests that illustrative examples of domain-specific documents can be placed in appendices, especially if they relate to several entry words. A similar approach was adopted by Oxford 
Business Spanish Dictionary, which contains examples of business letters showing their general layout and format in a centre section. The primary reason for placing such examples in centre texts or in appendices is their complexity, their relatively large size, and the possibility of providing comparative and contrastive information, something which is difficult to do inside dictionary articles and at the same time keep the necessary focus.

Writing, editing and revision for the purposes of lexicographic functions can be divided into two levels. The macro-level concerns paragraphs and larger units of text and may affect dictionary functions in respect of design, layout and format. In contrast, the micro-level concerns lexis and syntax, e.g. terminology and phraseology, grammar and syntax, e.g. coherence and cohesion, and pragmatics, e.g. implicatures and presuppositions. This level is particularly interesting for business translation dictionaries. Firstly, dictionaries are excellent media for containing and presenting information about the micro-level elements of texts and, secondly, users need information about the micro-level in particular when producing TL texts. This is illustrated by Mossop (2001: 11-12), who explains that editing and revision involve checking texts to make sure that generally accepted grammar and spelling rules are complied with (copyediting), that the terminology is consistent, the text is unambiguous and has been culturally adapted (stylistic editing), and checking the text for errors and amending it accordingly (revising). Furthermore, Mossop (2001: 168) sees proofreading as an extension of editing and revision to the finalisation stage: it involves the comparison of the printer's proof with the manuscript and is limited to making corrections. Users of translation dictionaries will face the most serious problems and challenges at the micro-level, and lexicographers should focus on this level when planning and compiling bilingual business dictionaries.

A dictionary offering both cognitive and communicative functions such as the Oxford Business Spanish Dictionary should play a key role in translation activities, as it informs users of different contrastive aspects regarding one or both languages. The English learners' dictionaries, initially published in the 1930s, opened the trend for the inclusion of grammatical and cultural data on some basic aspects of the English language. Following this trend, some bilingual business dictionaries are also offering middle texts (lexicographers call them "middle matter") devoted to offering data on business matters. In the Oxford Business Spanish Dictionary, this part consists of a 42-page section (pages 253-295) with bilingual (Spanish-English) data on correspondence (254-272), curriculum vitae (272-280), using the telephone (283-286), the countries (286-294), and monolingual (only English) data on the euro. Our interest in this article is the bilingual section (English - Spanish ) on business correspondence.

\section{Business Correspondence}

Business correspondence is a recurrent topic of research in business discourse, focussed on both intralinguistic and interlinguistic issues. The former analyses models of writing different letters, from the letter of complaint (for example, to an Editor) to letters covering such topics as invitations, sympathy, and congratulations to friends; and more recently, business blogs (Bargiella-Chiappini and Harris, 1996; Boxer, 1993; Christie 2006; Sprague, 2007). The latter deals with more focused aspects, usually referring to genre similarities and differences in different languages 
(Fukushima, 2007; Vergaro 2005), and also in the same language (English) although by speakers outside the Inner Circle (Flowerdew and Wan 2006; Hartford and Mahboob, 2004; Mahboob, 1997). What this research acknowledges is that there is a rhetorical structure of business correspondence in English that is having a deep impact on similar documents produced in other languages, most of which seem to have opted for reproducing the macrostructure of English business letters. This is our point of departure: English and Spanish business letters adjust to the same rhetorical macrostructure, the one reproduced below as Table 1 (Van Nus 1999):

TABLE 1

Standard structural units of business letters (Flowerdew and Wan 2006: 135)

\begin{tabular}{|l|l|}
\hline Letterhead & Carries company information such as name, address \\
Inside Address & Gives name and address of receiver \\
Reference & Encodes the letter for filing purposes \\
Date & Includes date and town from where the letter was sent \\
Subject Line & Signals the beginning of the letter \\
Body of the letter & Prepare the body of the letter \\
Preclose & Making enquires, asking for samples, quoting prices, etc. \\
Close & Prepare for the close \\
Signature & Close the letter \\
Postscript & Includes information about sender such as name, position \\
\hline
\end{tabular}

Up till now, interlinguistic analysis related to the translation of business correspondence has not caught the attention of researchers. For example, a review of the articles published in translation journals (Meta, Target, Babel, The Translator) in the last five years shows that this issue has been neglected. Perhaps, the only relevant exception is Siepman (2006), who offers a critical review of cross-cultural differences between English, French and German academic writing. Although neither the text analysed nor the questions asked and answered by Siepman are related to business correspondence, his analysis merits our attention as it shows that there are cultural differences, even in genres used for disseminating knowledge.

In broad terms, our research moves in the same direction, although from different perspectives and objectives. Our perspective starts from our conviction that such an analysis is of much relevance owing to both quantitative reasons (English and Spanish are two international languages), and qualitative reasons: business correspondence is a kind of entrance to business success. If someone desires to start a business somewhere else, he or she has to write business letters at some initial point and such a letter may influence the future outcome of the relationship. Therefore, it is of the utmost importance to write them in accordance with the cultural conventions of the addressee. Similarly, and that is our final objective, if translation dictionaries usually include separate texts explaining business correspondence, we think it is adequate to analyse what they reproduce, identify similarities and differences and formulate "suggestions" for translating them with the hope that these will be incorporated in dictionary texts and therefore be of much help for translators everywhere. 


\section{Translating Business Correspondence in a Business English-Spanish dictionary}

The Oxford Business Spanish Dictionary contains a section on bilingual business correspondence. This section comprises the following information: (i) how to lay out a business letter; (ii) the specific layout of both English and Spanish business letters; (iii) useful phrases; (iv) closures; (v) written conventions and abbreviations; (vi) examples of business letters for requesting information, asking for samples, sales promotion, placing an order, invoice, statement of account, and receipt; (vii) examples of alternative modes of communication such as faxes, and e-mails. The layout of the letter uses the prototypical rhetorical macrostructure reproduced in Table 1 . This does not need any further comment. What we need is to understand how both languages phrase the different messages covered. For example, most business correspondence (if not all) begins when one party requests something from the other party, usually because the former party has found (on the Internet, in a catalogue, talking with colleagues, etc.) something which may suit him or her. The requested item can be a piece of information, a catalogue, a brochure, a sample of a material, etc. Example (1) is a typical business letter:

(1) Asking for samples (Oxford Business Spanish [260-261])

\begin{tabular}{|c|c|}
\hline Petición de muestras & Asking for samples \\
\hline The Frank Company & Estudios Vázquez \\
\hline 22 Blooming Place & Casa Matriz 18 de abril 2002 \\
\hline LONDON SW12 TeL: 020-8669 7868 & Apdo. de correos 3588 \\
\hline FAX: 020-8669 7866 & 04988 Valladolid \\
\hline The Sales Director & Registro de Compañías: 87 E 22 \\
\hline June Office Supplies & Teléfono/Fax: 983760923 \\
\hline 55 Dewey Road & \\
\hline Wolverhampton WW12 HRR 5 June 2002 & $\begin{array}{l}\text { email: vazquez@estudios.com } \\
\text { TextilesProfom } \\
\text { Camino de losAlpes } \\
\text { 027738Granada }\end{array}$ \\
\hline Dear Sir/Madam, & Señores \\
\hline $\begin{array}{l}\text { Thank you for sending us your brochures. We } \\
\text { are particularly interested in the Dollis range, } \\
\text { which would complement our existing stock. } \\
\text { We would be grateful if you could send us } \\
\text { samples of the whole range promptly, as we are } \\
\text { hoping to place an order soon for the autumn. }\end{array}$ & $\begin{array}{l}\text { Acuso recibo de su catálogo y le agradezco } \\
\text { su pronta atención. Antes de hacer un } \\
\text { pedido, le ruego que sirva remitirnos un } \\
\text { lote de muestras de los géneros presenta- } \\
\text { dos de las páginas } 254 \text { a 256, ref. } \\
\text { TAF.10/54/5/6. }\end{array}$ \\
\hline $\begin{array}{l}\text { Thanking you in advance, } \\
\text { Yours faithfully, }\end{array}$ & $\begin{array}{l}\text { Le saludo cordialmente y quedo a la } \\
\text { espera de su respuesta }\end{array}$ \\
\hline Mr T Jones & Juan Vázquez \\
\hline Manager & Propietario \\
\hline
\end{tabular}

In terms of contrastive politeness between Spanish and English, our analysis of example (1) indicates that English prefers using standard formulas indicating positive face whereas Spanish relies on using formulas of negative face. These are mostly found in the salutation, the body of the letter, and the preclose and close. 
The salutation is a formal greeting in a business letter. English business letters always start with the noun dear, whereas Spanish only uses estimado as equivalent, if the addressee is identified by his or her social or professional title. If this is not the case, Spanish has two options: (i) Sr./Sra./Señores; (ii) the frozen Spanish expression muy señor mío/muy señora mía. Recently, the generic señores, estimados señores, and muy señores míos and their English equivalent gentlemen (AmE) or Dear Sirs (BrE) demanded by prescriptive grammars are subject to social tension because they obscure the role of women in business, and consequently we recommend not to use any of them, as they are considered "not polite." Instead, translators should use the neutral Dear Sir/Madam and Sr/Sra. More personal letters can also be written and in this situation the English salutation is $M r, M r s$, or $M s$ plus (name) plus family name (only one, usually the father's one). Spanish tend to use Estimado/a Sr. or Sra. (depending whether the addressee is a man or a woman) plus (name) plus family name (usually two, the father and the mother's one). The Spanish term señorita for an unmarried woman is old-fashioned and many people consider it not polite. Finally, if you write a business letter to a friend use dear plus name in English and only name in Spanish. In sum, dear indicates closeness, whereas estimado shows social distance, although they are the only possible translation equivalent in a business letter.

The body of the text records the topic of the letter. Many letters are for requesting information, asking for samples and/or quotations, and placing an order. The body of the text of these letters usually starts by acknowledging how the sender took notice of the receiver's company (product, service, etc.). English thanks the addressee in straight and plain language, whereas Spanish tells how the sender heard of the other party, usually by acknowledging a previous contact before thanking the addressee. In addition, Spanish uses finite clauses while English resorts to non-finite ones. In conclusion, English favours closeness of the participants, whereas Spanish does not, thereby reinforcing social distance.

More interestingly is what occurs with the second paragraph in the body of the text of the English letter. English uses a hypothetical or unreal condition to make a suggestion or request ("we would be grateful if you could send us samples of the whole range promptly"), whereas the Spanish letter resorts to a que-clause (i.e., thatclause) with the prototypical Spanish verb for requesting (ruego) followed by the subjunctive of "servir" (sirva) which is used only when asking for something in a very polite way ("le ruego que sirva remitirnos..."). Both clauses mitigate the force of the suggestion or request, thus allowing the receiver to save his or her face; but they are very different syntactically and are therefore ideal candidates for inserting the above explanation in the dictionary in connection with their frequent use in business correspondence. In addition, the English letter uses positive face, whereas Spanish emphasises negative face: the Spanish sender juxtaposes paragraphs 1 and 2 and initiates his or her request with the adverb phrase antes de (before) indicating some kind of constraint before the commercial relationship takes off. Spanish seems to indicate we need some time of acquaintance before jumping into serious business relations.

Finally, another difference between both languages is the use of different syntactic patterns for performing the same semantic role, although from a different aspectual perspective. English uses the progressive in order to make sure that the action is in progress, and therefore emphasises co-operation (i.e., positive face), 
whereas Spanish uses a non-progressive form of the simple tense thus implying that the requested action be considered for future action (i.e., negative face). In case the Spanish sender needs a change of semantic role and to emphasise that the action is already in progress, he or she will never use a progressive aspect but a reflexive verb. For example, in (2), the Spanish reflexive verb preparase offers the same aspectual information differently. Instead of a progressive aspect, it uses a reflexive verb. English uses a progressive aspect which describes, according to Biber et al. 1999: 470), "activities or events that are in progress at a particular time, usually for a limited duration. The present progressive aspect describes events that are currently in progress or are about to take place in the near future."

\section{(2) Excerpts from Oxford Business Spanish Dictionary (260-261)}

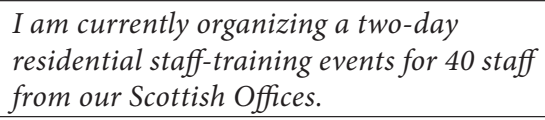

En estos momentos, Standford Publishing Co. se prepara para publicar una obra sobre el urbanismo en el cine europeo.

The preclose and the close are usually joined together. They only indicate that the letter is finishing. Although no new data will be added, there is also another difference in terms of politeness. English tends to be straightforward whereas Spanish offers a more elaborate close. The English expression thank you in advance also reinforces positive face as the sender thanks the receiver no matter the final outcome of the relationship. The Spanish sender, on the other hand, moves towards the negative face and again diminishes the positive meaning of cordialmente ('yours faithfully') by adding quedo a la espera de su respuesta (literally, 'I wait for your answer'), as if he or she does not want to thank in advance just in case the final outcome of the business relationship sours.

These differences are important. First, translators should be aware of them when translating business letters form English into Spanish or from Spanish into English. In addition, translation dictionaries should inform their users about them. A possible solution is to include information in the articles for words such as if, grateful, would, si, servir, and rogar and cross-refer users to the separate texts where an explanation can be given. A very easy one will consist in rearranging the section on useful phrases that this dictionary contains. Tables 2 and 3 show the section on useful phrases actually found in the dictionary, and our proposal of re-arrangement for helping translators to cope with the differences regarding politeness in both languages.

TABLE 2

Useful phrases in the Oxford Business Spanish Dictionary (258-259)

\begin{tabular}{|l|l|}
\hline Expresiones útiles & Useful phrases \\
\hline As requested I am forwarding you a [price & Acusamos recibo de su [catálogo, respuesta] \\
list, catalogue] & Recibí, con fecha de [fecha], su carta con \\
As stated in your letter of [date] concern- & respecto a.... \\
ing... & Le agradezco su carta y sus sugerencias \\
Thank you for your letter of [date] concern- & acerca de ... \\
ing/requesting... & En relación con la conversación telefónica de \\
Thank you for sending me a [catalogue, price & [fecha]... \\
list, brochure] & Conforme a su carta/fax de [fecha]...
\end{tabular}


Thank you for your enquiry of [date] concerning....

Further to our telephone conversation of [date]...

I am sorry to inform you that ...

I am writing to confirm our telephone conversation of [date]

I am writing to enquire whether ...

I am writing to express my dissatisfaction with...

I am writing to inform you that ...

I am pleased to inform you that ...

I am pleased to inform you that...

In reply to your letter/enquiry of [date] ...

I refer to your letter of [date] concerning...

I wish to draw your attention to ...

I wish to inform you that ...

I would be grateful if you could forward me

a [price list/catalogue]

Please find enclosed ...

With reference to your letter/order of [date]
De acuerdo a lo convenido en nuestra conversación telefónica de hoy, le mando... Me dirijo a ustedes a fin de solicitarles ... Le agradecería mucho si me pudiera mandar...

Rogamos que sirvan remitirnos su catálogo de ...

Por la presente le informo de la intención de ...

Me permito informarle acerca de ...

Le ruego tome nota de...

Adjunto le envío...

\section{TABLE 3}

\section{Re-arrangement of the section useful phrases}

\begin{tabular}{|l|l|}
\hline Expresiones útiles & Useful phrases \\
\hline a) se agradece el contacto previo: & a) thanking previous contact: \\
- Thank you for your letter of [date] concern- & - Le agradezco su carta y sus sugerencias \\
ing/requesting... & acerca de ... \\
- Thank you for sending me a [catalogue, price & - Le agradecería mucho si me pudiera \\
list, brochure] & mandar... \\
- Thank you for your enquiry of [date] & - Rogamos que sirvan remitirnos su \\
concerning.... & catálogo de \\
& \\
b) se reconoce el contacto previo: & b) acknowledging previous contact: \\
- As requested I am forwarding you a [price & - Acusamos recibo de su [catálogo, respu- \\
list, catalogue] & esta] \\
- Further to our telephone conversation of & - Recibí, con fecha de [fecha], su carta con \\
[date]... & respecto a.... \\
- In reply to your letter/enquiry of [date] .... & - En relación con la conversación telefónica \\
- I refer to your letter of [date] concerning... & de [fecha]... \\
- With reference to your letter/order of [date] & - Conforme a su carta/fax de [fecha]... \\
& - De acuerdo a lo convenido en nuestra \\
& conversación telefónica de hoy, le mando... \\
& c) getting into contact: \\
c) se entra en contacto: & - Me dirijo a ustedes a fin de solicitarles \\
- I am sorry to inform you that ... & \\
- I wish to draw your attention to ... & \\
- I wish to inform you that ... & \\
- I would be grateful if you could forward me a \\
[price list/catalogue]
\end{tabular}


d) se informa de algo:

- I am writing to confirm our telephone conversation of [date]

- I am writing to enquire whether ...

- I am writing to express my dissatisfaction

with...

- I am writing to inform you that ...

- I am pleased to inform you that ...

- Please find enclosed ...

e) Despedida

- Thank you in advance for...

- Yours faithfully (sincerely), etc. d) communicating something:

- Por la presente le informo de la intención de...

- Me permito informarle acerca de ...

- Le ruego tome nota de...

- Adjunto le envío...

e) Closures

- Le saludo cordialmente y quedo a la espera de su respuesta

\section{Conclusion}

The above analysis shows that people engaging in cross-border business communication should be aware of intralinguistic and interlinguistic politeness features. Translators of business texts normally use bilingual business dictionaries as help to solve various communicative and cognitive problems when translating business letters, but these dictionaries do not address pragmatic issues. We have demonstrated that politeness is a must in business communication for establishing successful relationships and that politeness plays a crucial role. Spanish and English use different rules that are determined by a mixture of cultural tradition, genre and convention. A good bilingual dictionary for translating business letters needs to contain information that can help users communicate in a way that does not offend the addressee, but existing dictionaries are insufficient. The analysis of the Oxford Business Spanish Dictionary shows that it lacks pragmatic information that can help users to translate politeness utterances found in business discourse. In particular, users need information about contrastive politeness between Spanish and English and we propose some lexicographical practices aiming at treating politeness in a consistent and systematic way in special sections in the dictionary. By including information on contrastive politeness in business discourse, lexicographers may design crafted bilingual business dictionaries that translators of business communication find valuable.

\section{REFERENCES}

Bargiela-Chiappini, F. and S. J. Harris (1996): "Request and status in business correspondence," Journal of Pragmatics 28, pp. 635-662.

Bell, R. T. (2000): Translation and Translating. Theory and Practice, London and New York, Longman.

Bergenholtz, H. and S. Nielsen (2006): "Subject-field components as integrated parts of LSP dictionaries," Terminology 12-2, pp. 281-303.

Bergenholtz, H. and S. TArp (eds.) (1995): Manual of Specialised Lexicography, Amsterdam/ Philadelphia, John Benjamins.

Bergenholtz, H. and S. TARp (2002): "Die moderne lexikographische Funktionslehre. Diskussionsbeitrag zu neuen und alten Paradigmen, die Wörterbücher als Gebrauchsgegenstände verstehen," Lexicographica 22, pp. 145-155.

Biber, D., Johansson, S., Leech, G., Conrad, S. and E. Finegan (1999): Longman Grammar of Spoken and Written English, Longman, London. 
Boxer, D. (1993): "Speech behaviour and social distance: The case of indirect complaints," Journal of Pragmatics 19, pp. 103-125.

Brown, P. and S. Levinson (1978): "Universals in language usage: Politeness phenomena," in Goody, E. (ed.), Questions and Politeness: Strategies in Social Interactions, Cambridge: Cambridge University Press. Reprinted (1987) as Politeness: Some Universals of Language Usage, Cambridge, Cambridge University Press.

Christie, G. (2006): “Golden rules of writing well," Chartered Accountants Journal 85-4: pp. 70 72.

Flowerdew, J. and A. WAN (2006): "Genre analysis of tax computation letters: How and why tax accountants write the way they do," English for Specific Purposes 25, pp. 133-153.

Fukushima, T. (2007): "Simulation in JFL: Business Writing," Simulation and Gaming 38-1, pp. 48-66.

Goffman, E. (1972): Relations in Public. Microstudies of the Public Order, New York, Harper.

Hartford, B. and A. Манвоов (2004): "Models of discourse in the letter of complaint," World Englishes 23-4, pp. 585-600.

López, S. and D. WATt (eds.) (2002): El Diccionario de Negocios Oxford. Español-inglés/inglesespañol. The Oxford Business Spanish Dictionary. Spanish-English/English-Spanish, Oxford, Oxford University Press.

Манвоов, А. (1997): "A cross cultural/linguistic study of complaints," paper presented at the $11^{\text {th }}$ Annual International Conference on Pragmatics and Language Learning, UrbanaChampaign, Illinois.

Mossop, B. (2001): Revising and Editing for Translators, Manchester/Northampton, St. Jerome Publishing.

Nielsen, S. (1994): The Bilingual LSP Dictionary. Principles and Practice for Legal Language, Tübingen, Gunter Narr Verlag.

Nord, C. (2005): Text Analysis in Translation. Theory, Methodology, and Didactic Application of a Model for Translation-Oriented Text Analysis, Amsterdam/New York, Rodopi.

PilegaARd, M. (1990): "Linguistic politeness in intercultural business communication," poster presentation at the 1990 IPrA Conference, Barcelona.

Pilegaard, M. (1997): "Politeness in written business discourse: A textlinguistic perspective." Journal of Pragmatics 28, pp. 223-244.

Siepman, D. (2006): "Academic writing and culture: An overview of differences between English, French, and German," Meta 51-1, pp. 131-150.

Sprague, R. (2007): "Business blogs and commercial speech: A new analytical framework for the $21^{\text {st }}$ Century," American Business Law Journal 44-1, pp. 127-159.

TARp, S. (2004): “Basic Problems of Learner’s Lexicography," Lexikos 14, pp. 222-252.

VAn Nus, M. (1999): "Can we count on your bookings of potatoes to Madeira? Corporate context and discourse practices in direct sales letters," in BARgiela-Chiappini, F. and C. Nickerson (eds.), Writing Business. Genres, Media and Discourse, London, Longman, pp. 181205.

Vergaro, C. (2005): “'Dear Sirs, I hope you will find this information useful': discourse strategies in Italian and English 'For Your Information' (FYI) letters," Discourse Studies 7-1, pp. 109-135.

Yeung, L. N.T. (1997): "Polite requests in English and Chinese business correspondence in Hong Kong," Journal of Pragmatics 27, pp. 505-522. 